\title{
A study of knowledge, attitude and practice on use of antibiotics and its resistance among the doctors and interns at urban tertiary care hospital: an interventional study
}

\author{
Manjusha Kalyani ${ }^{1}$, Anand Janagond ${ }^{2}$, Nimble Koshy ${ }^{1}$, Roshy Cheriyan ${ }^{1}$, \\ M. G. Keshannanvar ${ }^{1}$, Mallappa Shalavadi ${ }^{1}$, Chandrashekhar V. Mangannavar ${ }^{1 *}$
}

\author{
${ }^{1}$ Department of Clinical Pharmacy, B. V. V. Sangha's Hanagal Shri Kumareshwar College of Pharmacy, Bagalkot, \\ Karnataka, India \\ ${ }^{2}$ Department of Microbiology, S. N. Medical College, Bagalkot, Karnataka, India
}

Received: 16 December 2019

Revised: 02 March 2020

Accepted: 03 March 2020

\section{*Correspondence:}

Dr. Chandrashekhar V. Mangannavar,

Email: chandupharm75@gmail.com

Copyright: (c) the author(s), publisher and licensee Medip Academy. This is an open-access article distributed under the terms of the Creative Commons Attribution Non-Commercial License, which permits unrestricted non-commercial use, distribution, and reproduction in any medium, provided the original work is properly cited.

\begin{abstract}
Background: Infections due to resistant micro-organisms considerably increase the mortality rate, treatment cost, disease spread and duration of illness. The development of antibiotic resistance (AMR) is increasing steadily increasing over the last 10-15 years, which is a real threat to disease management. Many studies states that about 20$50 \%$ of antibiotic use unnecessary so decreasing the use of antibiotics is the first step to curb the AMR.

Methods: A questionnaire based prospective interventional study among the doctors. Systemic random sampling was applied. The pre tested structured questionnaire was used. Data's were summarised in the excel sheet, analysed by proportions, percentages and other statistical methods like Student $t$ test, Fisher test and Chi square test were used to check the association. The $\mathrm{p}>0.05$ was considered as significant.

Results: Out of 200 doctors, preliminary screening of 170 was included in the study and finally 156 participants were actively selected for analysis of results. Out of 156 participants, 55.1\% were MBBS Intern and $44.9 \%$ were doctors. High significance $(\mathrm{p}=0.0001)$ were found between pre and post knowledge, attitude and practice of doctors.

Conclusions: Further modes of studies have to perform to identify the determinants of attitude behaviour and motivation that lead people to use and misuse antibiotics. For effective outcome many more qualitative and quantitative studies are required. In addition, health care system should follow proper regulation and prescription policy as well as controls for prescription of antibiotic drugs.
\end{abstract}

Keywords: Antibiotic resistance, Attitude, Knowledge, Practice, Prescription, Systemic random sampling

\section{INTRODUCTION}

Infections due to resistant micro-organisms considerably increase the mortality rate, cost of treatment, disease spread and duration of illness. ${ }^{1-3}$ Until the end of $20^{\text {th }}$ century, Pharmaceutical companies were consistently able to develop new antibiotics that were active against most of the resistant bacterial strains. The development of antibiotic resistance among organism is increasing day by day and it has been steadily increasing over the last 10-15 years, which is a real threat to disease management. ${ }^{4}$ Many studies states that about $20-50 \%$ of antibiotic use are unnecessary so decreasing the use of antibiotics are the first step to curb the antibiotic resistance (AMR).$^{5-7}$

To rein in this threat of AMR a national antibiotic policy was developed, national surveillance database for antibiotic use was established and national centre for 
disease control (NCDC) is deputed to focus on AMR in the country. 8,9 Recently and for the first time WHO published list of antibiotic resistant "priority pathogen" causing greatest risk to human health; this is because our treatment option is running out as AMR is growing. The development of new antibiotics can bring to an end of antibiotic resistance in certain level, and it is equally important to use antibiotics wisely in humans, as well as to prevent unwanted use of these agents in food-animal production and also promote a rational use of antibiotics.

In order to initiate and to achieve effective outcome it is necessary to understand knowledge, attitude and practice (KAP) of doctors about the problem related to antibiotic resistance with this we are motivated to study KAP on use of antibiotics and its resistance among the doctors and interns.

\section{METHODS}

This was a prospective interventional study was done among the doctors and interns at HSK Hospital and Research centre, Bagalkot, Karnataka, after getting approval from IEC. This study was conducted from February 2018 to July 2018 for a period 6 months. By using Open Epi Software Version 2 we got, sample size as 145 round of to 156 . Systematic random sampling was applied to select the Doctors for the study. The 19 item of self-administered questionnaire collected information among doctors and knowledge, attitudes and practice about antibiotic prescribing, their perception of the importance of the problem of antibiotic resistance, their knowledge of the national prevalence of antibiotic resistance and local prevalence of antibiotic misuse, their beliefs about the causes of antibiotic resistance, and about current and potential interventions design to improve antibiotic stewardship.

Data were collected about their current specialty, the frequency with which they prescribed antibiotics, and past training in antibiotic prescribing. To assess the knowledge of the prevalence of antibiotic resistance, doctors were asked about the prevalence of resistance in the hospital for specific bacterium (Methicillin resistant Staphylococcus aureus and E. coli) antibiotic combinations relevant to clinical practice. ${ }^{16}$

\section{Inclusion criteria}

Doctors and interns of departments like medicine, surgery, orthopaedics, skin, paediatrics and microbiology were included.

\section{Exclusion criteria}

Other healthcare professionals of remaining departments were excluded.

\section{Study procedure}

The study respondents were verbally informed about the studies. The questionnaire was distributed to the participants and collects it back on the same day. After one week awareness were provided by the means of leaflets and oral discussion on recent Antibiotic resistance. Again the same questionnaire was collected from the same participants.

\section{Flow of study procedure}

Baseline KAP about antibiotics use in selected doctors. Afterwards, awareness to the doctors is provided by leaflets and oral discussion about antibiotic resistance followed by questionnaire.

\section{Statistical analysis}

Percentages were calculated for the categorical data. Data analysis will be done using the statistical methods like percentages, proportion, Student t-test and Chi square test, Fisher test to arrive at a conclusion for finding the significant differences.

\section{Measures and scores}

For each questions scoring were given, and for each right answers higher score has given, followed by low score for appropriate answer and no score for wrong answers.

Knowledge question score: 13 item of questions were used to assess the knowledge, in which 62 is the total score one can score, the score $\geq 31$ were categorized as good knowledge and below 31 categorized as average knowledge.

Attitude question score: 16 item of questions were used to assess the Attitude, in which 48 is the total score one can score, the score $\geq 24$ were categorized as Positive attitude and below 23 categorized as negative attitude.

Table 1: Operational definitions.

\begin{tabular}{|c|c|}
\hline $\begin{array}{l}\text { Antibiotic } \\
\text { resistance }\end{array}$ & $\begin{array}{l}\text { It's an emerging medical threat in India } \\
\text { with increasing nosocomial infection due } \\
\text { to antimicrobial resistance due to } \\
\text { irrational dose, duration and off-label } \\
\text { uses may create havoc in the future. It's } \\
\text { up-to healthcare professionals to analyze } \\
\text { and advice on rational use of } \\
\text { antimicrobials with regional guidelines. }\end{array}$ \\
\hline Knowledge & $\begin{array}{l}\text { The facts, information and skills } \\
\text { acquired through experience or } \\
\text { education. }\end{array}$ \\
\hline Attitude & A settled way of thinking \\
\hline Practice & $\begin{array}{l}\text { Actual application or use of an idea, } \\
\text { belief, or method, as opposed to theories } \\
\text { relating to it. }\end{array}$ \\
\hline
\end{tabular}


Practice question score: 21 items were used to assess the practice, in which 60 is the total score one can score, the score $\geq 30$ were categorized as good practice and below 29 categorized as poor practice.

\section{RESULTS}

\section{Demographic details of study participants}

In present study 200 doctors (MBBS-Intern, PG, MD/MS, and doctors) were enrolled, after the preliminary screening $170(85 \%)$ were also included in the study and finally 156 participants were actively selected for analysis of results and 14 doctors were discounted from the middle of the study.

\section{Assessment of knowledge}

\section{Pre-awareness for antibiotic prescription information}

In the beginning of this study most of the doctors, out of 156 participants, about 120 (76.92\%) of doctors have not undergone any awareness/training programmes relevant to antibiotic prescription and practice. Only 36 (23.03\%) of doctors have undergone training programme. In which $31(19.9 \%)$ of MBBS intern received training suitable for antibiotic prescription. This baseline information indicates that majority of doctors were not having any awareness and training programme for the recent updates and antibiotic prescription practice as shown in Table 1a.

\section{Post- awareness for antibiotic prescription information}

After baseline information (pre) obtained from 156 doctors, all these doctors were subjected for awareness/training about the rationality of antibiotic prescription and antibiotic resistance practice related information in the form of pamphlets, brochure and presentation followed by discussion provided to all. During this awareness programme 106 (68.69\%) doctors have participated actively. Only 50 (32\%) doctors were not actively participated. And $43(27.6 \%)$ of doctors already had training programme. Of which, 63 (40.4\%) MBBS interns have received training suitable for antibiotic prescription (Table 1a).

Pre-knowledge of participants with the scenario of antibiotic prescription

In this study we assessed the confident level of doctors with respect to antibiotic prescription practice. Out of 156 subjects, $109(69.9 \%)$ are confident of making an accurate diagnosis of infection. Total of 47 (36.6\%) were unconfident for accurate diagnosis of infection. Similarly $106(67.9 \%)$ were confident in selection of correct antibiotic and $50(32.1 \%)$ are unconfident in making decision for selection of correct antibiotic. In continuation, $108(69.2 \%)$ are confident and 48 (30.8\%) are unconfident to select the correct dose and interval of administration of antibiotics. $92(59 \%)$ of doctors were confident and $64(41.1 \%)$ of the doctors were unconfident for using a combination therapy. Nearly, 110 (70.5\%) of doctors are confident and $46(29.5 \%)$ are unconfident for choosing between IV and PO administration. Similarly, 110 (70.5) of doctors were very confident and 46 (29.53\%) were unconfident for interpreting microbiologic result provided for proper selection of antibiotic. The 105 (67.3) of doctors were confident and 51 (32.7\%) were unconfident for planning of antibiotic treatment duration appropriately (Table 1a).

Table 1a: Knowledge of study subject in the scenario of antibiotic prescription.

\begin{tabular}{|c|c|c|c|c|}
\hline \multirow{2}{*}{$\begin{array}{l}\text { Knowledge of study subject } \\
\text { in the scenario of antibiotic } \\
\text { prescription }\end{array}$} & \multicolumn{2}{|c|}{$\begin{array}{l}\text { Pre } \\
(n=156)\end{array}$} & \multicolumn{2}{|c|}{$\begin{array}{l}\text { Post } \\
(n=156)\end{array}$} \\
\hline & C & $\mathbf{U C}$ & C & UN \\
\hline $\begin{array}{l}\text { Making an accurate } \\
\text { diagnosis }\end{array}$ & 109 & 29 & 99 & 56 \\
\hline $\begin{array}{l}\text { Not prescribing an } \\
\text { antibiotic if the patient has } \\
\text { fever but no severity } \\
\text { criteria, and if you are not } \\
\text { sure about the diagnosis }\end{array}$ & 73 & 56 & 96 & 54 \\
\hline $\begin{array}{l}\text { Choosing the correct } \\
\text { antibiotic }\end{array}$ & 106 & 39 & 108 & 47 \\
\hline $\begin{array}{l}\text { Choosing the correct dose } \\
\text { and interval of } \\
\text { administration }\end{array}$ & 108 & 39 & 114 & 40 \\
\hline $\begin{array}{l}\text { Using the combination } \\
\text { therapy if appropriate }\end{array}$ & 92 & 48 & 100 & 38 \\
\hline $\begin{array}{l}\text { Choosing between IV and } \\
\text { PO administration }\end{array}$ & 110 & 33 & 123 & 31 \\
\hline $\begin{array}{l}\text { Interpreting microbiologic } \\
\text { result }\end{array}$ & 110 & 30 & 135 & 19 \\
\hline $\begin{array}{l}\text { Planning to streamline/stop } \\
\text { the antibiotic treatment } \\
\text { according to clinical } \\
\text { evaluation and } \\
\text { investigations }\end{array}$ & 11 & 26 & 113 & 41 \\
\hline $\begin{array}{l}\text { Planning the duration of } \\
\text { the antibiotics treatment }\end{array}$ & 105 & 34 & 114 & 40 \\
\hline
\end{tabular}

Post-knowledge of participants with the scenario of antibiotic prescription

In this study we assessed the confident level of doctors about the antibiotic prescription practice. Out of 156 subjects $99(63.5 \%)$ were confident of making an accurate diagnosis of infection. Total of 57 (36.9\%) were unconfident with accurate diagnosis of infection. Similarly, $108(69.2 \%)$ were confident on selection of correct antibiotic and $48(27.9 \%)$ were unconfident in making decision for selection of correct antibiotic. In continuation, $114(75.3 \%)$ were confident and $42(24.7 \%)$ were unconfident to select the correct dose and interval of administration of antibiotics. There were $100(67.1 \%)$ of doctors are confident and $56(32.9 \%)$ of the doctors were unconfident for using a combination therapy. Nearly, 123 
(80.5\%) of doctors were confident and $33(19.4 \%)$ are unconfident for choosing between IV and PO administration. Similarly, $135(86.6 \%)$ of doctors were very confident and $21(13 \%)$ were unconfident for interpreting microbiologic result provided for proper selection of antibiotic. Among the doctors 114 (95.2\%) were confident and $42(26.3 \%)$ were unconfident for planning of antibiotic treatment duration appropriately (Table 1a).

\section{Pre-knowledge of study subjects on cause of antibiotic} resistance

In 156 participants, totally $102(65.38 \%)$ doctors had given feedback as responsibility towards patient play an important role in preventing the cause of antibiotic resistance in patient. In which, $139(89.1 \%)$ doctors had given the reason of self medication and antibiotic misuse as the major cause of antibiotic resistance as shown in Table $1 \mathrm{~b}$.

Table 1b: Knowledge of study subject on cause for antibiotic resistance.

\begin{tabular}{|llllllll|}
\hline $\begin{array}{l}\text { Questions } \\
\text { Knowledge of }\end{array}$ & Pre $(\mathrm{n}=156)$ & & \multicolumn{3}{c|}{ Post $(\mathrm{n}=156)$} \\
$\begin{array}{l}\text { study subject } \\
\text { on cause for } \\
\text { antibiotic } \\
\text { resistance }\end{array}$ & Yes & No & $\begin{array}{l}\text { Don't } \\
\text { know }\end{array}$ & Yes & No & $\begin{array}{l}\text { Don't } \\
\text { know }\end{array}$ \\
\hline $\begin{array}{l}\text { Responsibility } \\
\text { of patient }\end{array}$ & 102 & 28 & 26 & 135 & 9 & 12 \\
\hline $\begin{array}{l}\text { Self medication } \\
\text { and antibiotic } \\
\text { misuse }\end{array}$ & 139 & 5 & 12 & 136 & 18 & 2 \\
\hline
\end{tabular}

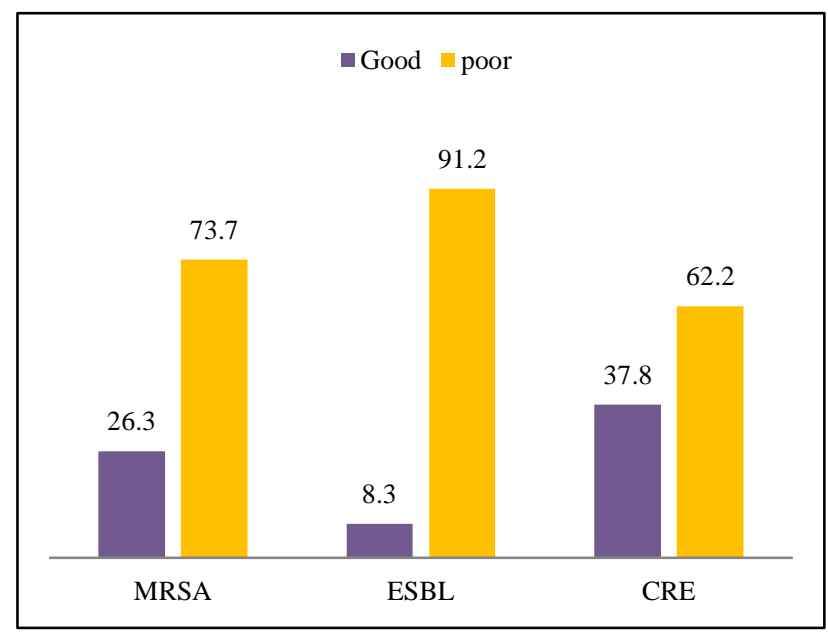

Figure 1a: Knowledge about correct ratio of prevalence of resistant strains.

In present study, three questions were asked to doctors to assess the knowledge about prevalence of resistant strain of MRSA, ESBL and CRE at our hospital. In which, 41 $(26.3 \%)$ doctors were believed for existence of correct ratio of prevalence of resistant strains of MRSA. Nearly, $115(73.7 \%)$ doctors have poor knowledge of MRSA resistance and prevalence. Similarly, only $13(8.3 \%)$ doctors were having good knowledge of ESBL prevalence and $143(91.2 \%)$ were having very poor knowledge of ESBL prevalence of resistance at our hospital. Similarly, for the CRE resistance prevalence only 59 (37.8\%) doctors were aware about the resistance. And remaining $97(62.2 \%)$ had no/poor knowledge about the prevalence of CRE resistance. This information indicates more than $75 \%$ of doctors were not aware about the exact prevalence of resistance of above three microbial strains, shown in Figure 1a.

Post-knowledge of study subjects on cause of antibiotic resistance

In 156 Participants, totally 135 (86.5\%) doctors have given feedback as responsibility of cause of antibiotic resistance in patient. Out of which $136(87.2 \%)$ doctors are given the reason of self medication and antibiotic misuse were major cause for antibiotic resistance. In present study, three questions were asked to doctors to access the knowledge about prevalence of resistant strain of MRSA, ESBL and CRE at our hospital. In which, 104 $(66.7 \%)$ doctors were believed for existence of correct ratio of prevalence of resistant strains of MRSA. Nearly $35(22.4 \%)$ doctors have poor knowledge of MRSA resistance and prevalence. And $85(54.5 \%)$ doctors were having good knowledge of ESBL prevalence and 25 (16\%) were having very poor knowledge of ESBL prevalence of resistance at our hospital. Similarly, for the CRE resistant and prevalence, about 122 (78.2\%) doctors were aware about its resistance. And remaining 39 (25\%) have no/poor knowledge about the prevalence of CRE resistance. This information indicates that $34 \%$ of doctors are not aware about the exact prevalence of resistance on above three microbial strains after the provided awareness as shown in Figure $1 \mathrm{~b}$.

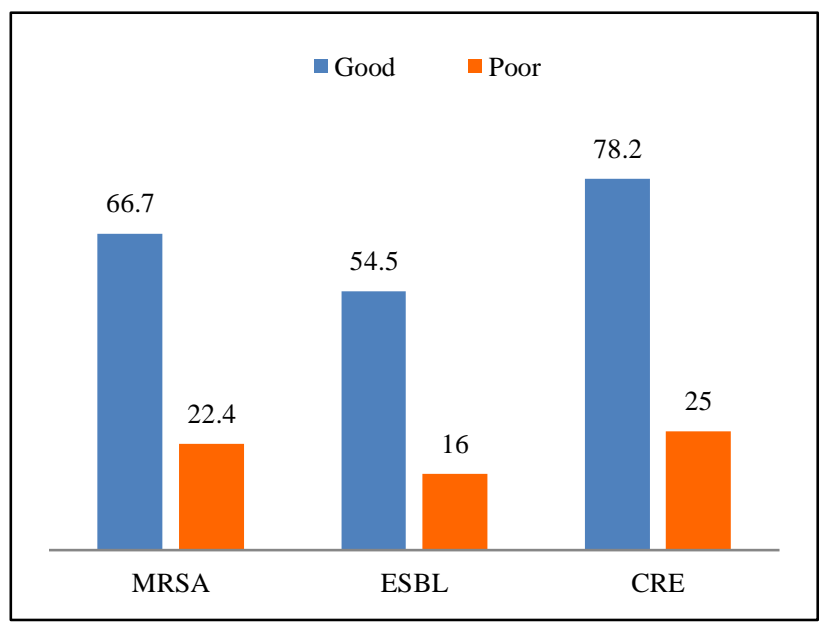

Figure 1b: Knowledge about correct ratio of prevalence of resistant strains. 
In pre and post intervention of knowledge, those with age group of 20-30 years had the good knowledge and overall in post intervention should have significant difference $\left(\chi^{2}=11.1 ; \quad \mathrm{p}<0.011\right.$ and $\mathrm{t}=6.969 ; \quad \mathrm{p}<0.001 \mathrm{at} 95 \%$ confidence interval) in knowledge gain. Similarly, while considering experience of professional knowledge within 1 years of experienced doctors, MBBS interns have the significant $\left(\chi^{2}=22.6 ; \quad \mathrm{p}<0.0 .000\right)$ good knowledge in prescription of antibiotics (Table 5).

\section{Assessment of attitude}

Pre-attitude of participants on antibiotic prescription and potential cause of antibiotic resistance

In present study, out of 156 doctors $126(80.76 \%)$ were having good attitude of antibiotics prescription and 30 $(19.22 \%)$ were having negative attitude of antibiotic prescription habit. In relation to antibiotic resistance, 118 $(75.6 \%)$ were confident and $38(24.4 \%)$ were unconfident and given reason of resistant that it may be due to too many antibiotics. And total of $117(75 \%)$ were confident and $39(25 \%)$ says due to many broad spectrum antibiotics. About 94 (60.2\%) doctors were confident and 62 (39.7) were expressed unconfident for long duration of antibiotic treatment is unnecessary. Most of doctors 78 $(50 \%)$ were confident and $78(50 \%)$ were unconfident and expressed that low dose (not appropriated dose) is the major reason for antibiotic resistance. Nearly, 93 (59.6\%) were confident and $63(36.4 \%)$ doctors were unconfident about excessive use of antibiotics in livestock (animals). $105(67.3 \%)$ were confident and 51 (32.7\%) were unconfident of saying not removing the focus of infection as the main reason of resistance. 58 (37.6\%) were confident and $98(62.8 \%)$ were unconfident of saying paying too much attention to pharmaceutical representatives rather than real clinical evidence, shown in Table 2.

Post-attitude of participants on antibiotic prescription and potential cause of antibiotic resistance

In present study, out of 156 doctors, 146 (93.6\%) were having good attitude of antibiotics prescription and 10 $(6.4 \%)$ were having negative attitude of antibiotic prescription habit. In relation to antibiotic resistance, 151 (96.8\%) were confident and 5 (3.2\%) were unconfident and have given reason that resistant may be due to too many antibiotics. Total of $151(96.8 \%)$ were confident and $5(3.2 \%)$ were due to many antibiotics particularly broad spectrum antibiotics. Among the doctors 148 (94.9\%) were confident and $8(5.1 \%)$ were expressed that unconfident for long duration of antibiotic treatment unnecessary. Most of doctors 141 (90.3\%) were confident and $15(9.6 \%)$ were unconfident and expressed that low dose (not appropriated dose) is major reason for antibiotic resistance. Nearly $139(89.1 \%)$ doctors were confident and $20(10.9 \%)$ doctors are unconfident about excessive use of antibiotics in livestock and animals. 119 (76.3\%) were confident and $37(23.7 \%)$ were unconfident of saying not removing the focus of infection as the main reason of resistance. $58(37.6 \%)$ were confident and 44 $(28.2 \%)$ are confident of saying paying too much attention to pharmaceutical representatives rather than real clinical evidence (Table 2).

Table 2: Attitude.

\begin{tabular}{|c|c|c|c|c|}
\hline Questions & \multicolumn{2}{|c|}{$\begin{array}{l}\text { Pre } \\
(n=156)\end{array}$} & \multicolumn{2}{|c|}{$\begin{array}{l}\text { Post } \\
(n=156)\end{array}$} \\
\hline $\begin{array}{l}\text { Attitude of study subjects } \\
\text { on potential cause for } \\
\text { antibiotic resistance }\end{array}$ & $\mathbf{C}$ & $\mathbf{U N}$ & $\mathbf{C}$ & $\mathbf{U N}$ \\
\hline $\begin{array}{l}\text { Too many antibiotic } \\
\text { prescription }\end{array}$ & 118 & 12 & 151 & 1 \\
\hline $\begin{array}{l}\text { Too many broad spectrum } \\
\text { antibiotics }\end{array}$ & 117 & 17 & 151 & 1 \\
\hline $\begin{array}{l}\text { Too long durations of } \\
\text { antibiotic treatment }\end{array}$ & 94 & 18 & 148 & 0 \\
\hline Too low dose of antibiotic & 78 & 33 & 141 & 3 \\
\hline $\begin{array}{l}\text { Excessive use of antibiotics } \\
\text { in livestock }\end{array}$ & 93 & 24 & 139 & 3 \\
\hline Poor hand hygiene & 83 & 29 & 118 & 31 \\
\hline $\begin{array}{l}\text { Not removing the focus of } \\
\text { infection }\end{array}$ & 105 & 19 & 119 & 33 \\
\hline $\begin{array}{l}\text { Paying too much attention } \\
\text { to pharmaceutical } \\
\text { representatives }\end{array}$ & 58 & 46 & 112 & 31 \\
\hline $\begin{array}{l}\text { Attitude of study subjects } \\
\text { about measure on } \\
\text { rationalizing antibiotic } \\
\text { prescribing }\end{array}$ & $\mathbf{H}$ & UH & $\mathbf{H}$ & $\mathbf{U H}$ \\
\hline $\begin{array}{l}\text { Educational sessions on } \\
\text { prescribing }\end{array}$ & 129 & 10 & 155 & 0 \\
\hline $\begin{array}{l}\text { Availability of } \\
\text { local/national } \\
\text { guidelines/policies/ } \\
\text { protocol }\end{array}$ & 136 & 6 & 154 & 0 \\
\hline $\begin{array}{l}\text { Availability of } \\
\text { local/national resistance } \\
\text { data }\end{array}$ & 128 & 7 & 144 & 1 \\
\hline $\begin{array}{l}\text { Restriction of prescription } \\
\text { of certain antibiotics }\end{array}$ & 108 & 11 & 138 & 8 \\
\hline $\begin{array}{l}\text { Restriction of prescription } \\
\text { of all antibiotics }\end{array}$ & 59 & 48 & 114 & 10 \\
\hline $\begin{array}{l}\text { Regular audit and } \\
\text { feedback on antibiotic } \\
\text { prescribing }\end{array}$ & 107 & 8 & 142 & 6 \\
\hline
\end{tabular}

Post-measures on rationalizing antibiotic prescribing

In present study, out of 156 doctors, 155 (99.4\%) doctors expressed that continuation education sessions will be helpful to understand about the rationalization of antibiotic prescription. About 154 (98.7\%) doctor's states as helpful with availability of local/national guidelines /policies/protocol to ensure the rationalizing antibiotics. Similarly, $138(88.5 \%)$ doctors expressed that certain restriction of prescription un-necessaries. Some of doctors 
$114(73.1 \%)$ saying those on restriction of prescription of all antibiotics are helpful. And the 142 (91\%) doctors expressed that regular antibiotic use and misuse audit and feedback and awareness programme will definitely ensure the rationalising of antibiotic prescription habit (Table 2).

In the measure of attitude towards their education about antibiotic prescription most of doctors had significant positive attitude $\left(\chi^{2}=11.1 ; \mathrm{p}<0.011\right.$ and $\mathrm{t}=10.848 ; \mathrm{p}<0.001$ at $95 \%$ confidence interval) in post intervention studies itself. Especially, MBBS interns have shown more positive attitude in learning, and improving in prescription of rational antibiotics to reduce the resistance (Table 4).

\section{Assessment of practice}

Pre-practice of study subject on inappropriate prescription of antibiotics in the hospital

In the present study, out of 156 doctors, 91 (58.4\%) doctors expressed that $10-50 \%$ of antibiotic prescription were unnecessary or inappropriate and remaining 65 (41.6\%) were not sure about the inappropriate use of antibiotics. In contrast, $41(26.3 \%)$ was MBBS Interns and $50(32.1 \%)$ doctors (PG/MD/MS) were saying 10$50 \%$ antibiotics are inappropriate prescriptions at our hospital.

Post-practice of study subject on inappropriate prescription of antibiotics in the hospital

Among of 156 doctors, 140 (89.2\%) doctors expressed that $10-50 \%$ of antibiotic prescription were unnecessary or inappropriate and remaining $16(10.25 \%)$ not sure about the inappropriate use of antibiotics. In contrast, 68 (43.3\%) of MBBS Interns and 72 (45.9\%) doctors (PG/MD/MS) were saying $10-50 \%$ antibiotics were inappropriate prescription at our hospital.

Table 3a: Practice.

\begin{tabular}{|lllll|}
\hline & \multicolumn{2}{l}{$\begin{array}{l}\text { Pre } \\
\text { Questions }\end{array}$} & \multicolumn{3}{l|}{$\begin{array}{l}\text { Post } \\
\text { (n=156) }\end{array}$} \\
\hline $\begin{array}{l}\text { Practice for rationalising } \\
\text { antibiotic prescribing }\end{array}$ & H & UH & H & UH \\
\hline $\begin{array}{l}\text { Computer aided prescribing } \\
\text { Presence of an antimicrobial } \\
\text { management team }\end{array}$ & 10 & 34 & 130 & 4 \\
\hline $\begin{array}{l}\text { Readily accessible } \\
\text { microbiological advice }\end{array}$ & 120 & 3 & 119 & 12 \\
\hline $\begin{array}{l}\text { Readily accessible advice } \\
\text { from ID physician }\end{array}$ & 117 & 4 & 120 & 1 \\
\hline $\begin{array}{l}\text { Readily accessible advice } \\
\text { from a pharmacist }\end{array}$ & 93 & 12 & 116 & 13 \\
\hline $\begin{array}{l}\text { Readily accessible advice } \\
\text { from infection control team }\end{array}$ & 114 & 8 & 140 & 12 \\
\hline $\begin{array}{l}\text { Advice from senior colleague } \\
\text { Speaking to a pharmaceutical }\end{array}$ & 723 & 4 & 138 & 9 \\
\hline representative & 25 & 115 & 26 \\
\hline
\end{tabular}

H- helpful, UH- unhelpful
Pre practice of study subjects for rationalizing antibiotic prescribing

Out of 156 participants, 70 doctors (44.9\%) expressed that computer aided prescribing were helpful in rationalizing the prescription and $100(64.1 \%)$ doctors showed interest on the presence of an antimicrobial management team in each hospital definitely helpful to combat of irrational use of antibiotics. About 120 (76.9\%) doctors expressed about facility for readily accessible microbiological advice for rationalisation of antibiotic prescription. About 117 (75.9\%) doctors have expressed that drug information system at each hospital and discussions with physician were very helpful in rationalisation. Similarly, 93 (59.6\%) of doctors have expressed obtaining correct information on Clinical Pharmacist help to access the rationality of an antibiotic prescriptions. Nearly $114(73.1 \%)$ and 123 (78.84\%) have advised for infection control team help and taking senior colleague advice, will be great helpful. Only $72(46.15 \%)$ said helpful on speaking to a pharmaceutical representative as shown in Table 3a.

Table 3b: Practice.

\begin{tabular}{|c|c|c|c|c|c|c|}
\hline \multirow[b]{2}{*}{$\begin{array}{l}\text { Questions } \\
\text { Practice of study } \\
\text { subjects on } \\
\text { potential } \\
\text { intervention to } \\
\text { combat AMR }\end{array}$} & \multicolumn{3}{|c|}{ Pre $(n=156)$} & \multicolumn{3}{|c|}{ Post $(n=156)$} \\
\hline & $\mathbf{U}$ & $\mathbf{N U}$ & US & $\mathbf{U}$ & $\mathbf{N U}$ & US \\
\hline $\begin{array}{l}\text { Antimicrobial } \\
\text { usage policy }\end{array}$ & 143 & 2 & 11 & 155 & 1 & 0 \\
\hline $\begin{array}{l}\text { Reduction of } \\
\text { antibiotic use for } \\
\text { OP setting }\end{array}$ & 131 & 15 & 10 & 149 & 0 & 7 \\
\hline $\begin{array}{l}\text { Establish national } \\
\text { action plan }\end{array}$ & 137 & 2 & 17 & 155 & 0 & 1 \\
\hline $\begin{array}{l}\text { Develop } \\
\text { institution } \\
\text { guidelines for } \\
\text { antimicrobial use }\end{array}$ & 136 & 4 & 116 & 149 & 0 & 7 \\
\hline $\begin{array}{l}\text { Education on } \\
\text { antimicrobial }\end{array}$ & 142 & 2 & 12 & 153 & 0 & 3 \\
\hline
\end{tabular}

U- Useful, NU-Not useful, NS- Not sure

Post-practice of study subjects for rationalizing antibiotic prescribing

Out of 156 participants, 130 doctors $(83.3 \%)$ expressed that computer aided prescribing was helpful in rationalizing the prescription and $129(82.7 \%)$ doctors showed interest that presence of an antimicrobial management team in each hospital definitely will be helpful to combat irrational use of antibiotics. About 119 (76.3) doctors have expressed that facility for readily accessible microbiological advice would be more helpful for rationalisation of antibiotic prescription. Most of doctors that is, $120(76.9 \%)$ have expressed that drug information system at each hospital and discussions with physician were very helpful in rationalisation. Similarly 
$116(74.4 \%)$ of doctors have expressed obtaining correct information on clinical pharmacist help to access the rationality of an antibiotic prescriptions. Nearly, 140 $(89.7 \%)$ and $138(88.5 \%)$ are advised for infection control team help and taking advice from senior colleague will be great helpful. Only 115 (73.7\%) says helpful on speaking to a pharmaceutical representative (Table $3 \mathrm{a}$ ).

Table 4: Pre and post intervention of KAP among doctors against antimicrobial resistance.

\begin{tabular}{|c|c|c|c|}
\hline & $\chi^{2}$ value & P value & Result \\
\hline $\begin{array}{l}\text { Pre-knowledge } \\
\text { with age }\end{array}$ & $1.07 *$ & 0.785 & Insignificant \\
\hline $\begin{array}{l}\text { Post-knowledge } \\
\text { with age }\end{array}$ & $11.1 *$ & 0.011 & Significant \\
\hline $\begin{array}{l}\text { Pre-knowledge } \\
\text { with gender }\end{array}$ & $0.526 * *$ & 0.47 & Insignificant \\
\hline $\begin{array}{l}\text { Post-knowledge } \\
\text { with gender }\end{array}$ & $0.819 *$ & 0.365 & Insignificant \\
\hline $\begin{array}{l}\text { Pre-knowledge } \\
\text { with education }\end{array}$ & $3.011 * *$ & 0.082 & Insignificant \\
\hline $\begin{array}{l}\text { Post-knowledge } \\
\text { with education }\end{array}$ & $1.24 *$ & 0.266 & Insignificant \\
\hline $\begin{array}{l}\text { Pre-knowledge } \\
\text { with experience }\end{array}$ & $5.22 *$ & 0.39 & Insignificant \\
\hline $\begin{array}{l}\text { Post-knowledge } \\
\text { with experience }\end{array}$ & $22.6^{*}$ & 0.000 & Significant \\
\hline $\begin{array}{l}\text { Pre-attitude } \\
\text { with education }\end{array}$ & $5.08 * *$ & 0.02 & Significant \\
\hline $\begin{array}{l}\text { Post-attitude } \\
\text { with education }\end{array}$ & $2.49 *$ & 0.12 & Insignificant \\
\hline $\begin{array}{l}\text { Pre-attitude } \\
\text { with experience }\end{array}$ & $1.63 * *$ & 0.89 & Insignificant \\
\hline $\begin{array}{l}\text { Post-attitude } \\
\text { with experience }\end{array}$ & $8.29 *$ & 0.014 & Significant \\
\hline $\begin{array}{l}\text { Pre-practice } \\
\text { with education }\end{array}$ & $3.83 * *$ & 0.05 & Significant \\
\hline $\begin{array}{l}\text { Post-practice } \\
\text { with education }\end{array}$ & $0.45 * *$ & 0.50 & Insignificant \\
\hline $\begin{array}{l}\text { Pre-practice } \\
\text { with experience }\end{array}$ & $9.03 *$ & 0.108 & Insignificant \\
\hline $\begin{array}{l}\text { Post-practice } \\
\text { with experience }\end{array}$ & $19.34 * *$ & 0.0016 & Significant \\
\hline
\end{tabular}

*Fisher test; $*$ *Chi-square test

Table 5: Summary of pre and post KAP.

\begin{tabular}{|llll|}
\hline Pre knowledge & N & Mean & SEM \\
\hline Post knowledge & 156 & $40.11 \pm 9.553$ & 0.765 \\
\hline Pre attitude & 156 & $45.94 \pm 6.456$ & 0.492 \\
\hline Post attitude & 156 & $42.32 \pm 6.557$ & 0.525 \\
\hline Pre practice & 156 & $41.01 \pm 8.857$ & 0.257 \\
\hline Post practice & 156 & $51.06 \pm 8.078$ & 0.709 \\
\hline Pre total score & 156 & $192.61 \pm 35.372$ & 2.832 \\
\hline Post total score & 156 & $227.57 \pm 18.236$ & 1.460 \\
\hline
\end{tabular}

Pre-practice of study subject on potential intervention to combat AMR

In final stage of this study, doctors of $143(91.7 \%)$ believed that Antimicrobial usage policy at national level as useful. About $131(84 \%)$ of doctor perceived that Reduction of antibiotic use for OP setting will be useful. Doctors of $137(87.8 \%)$ and $136(87.2 \%)$ believed in establishing national action plan updates and institutional action plan was helpful. About 142 (91.02\%) doctors saying that regular education on Antimicrobial therapy for prescribers will be helpful in combat of AMR (Table 3b).

\section{Post-practice of study subject on potential intervention to} combat AMR

In final stage of this study, 155 (99.4\%) of doctors believed in proper development of Antimicrobial usage policy at national level will be helpful. The 149 (95.5\%) perceived that reduction of antibiotic use for OP setting as very helpful. Doctors of $137(87.8 \%)$ and $136(87.2 \%)$ perceived that establishing national action plan updates and institutional action plan was helpful. Doctors of 142 $(91.02 \%)$ saying regular education on Antimicrobial therapy for prescribers on up-to date was helpful in combat of AMR (Table 3b).

Pre and post intervention of KAP among doctors against antimicrobial resistance with respect to their age, gender, education qualification and experience were analysed with appropriate test (Fisher test and Chi square test) and summarised in Table 4.

In pre and post intervention measure of practice towards their experience about antibiotic prescription for most of doctors has significant Good practice $\left(\chi^{2}=19.34 ; \mathrm{p}<0.0016\right.$ and $\mathrm{t}=11.134 ; \mathrm{p}<0.001$ at $95 \%$ confidence interval) in post intervention studies itself. Especially, MBBS interns have shown more good practice in improving the prescription habit to rationalise the antibiotic therapy (Table 5).

\section{DISCUSSION}

This study reveals that most of the MBBS interns have realised that antibiotic resistance is an important problem globally and national health policy makers and government should take strict actions to rationalise the antibiotic use. Present findings are consistent with similar studies done in other parts of the works. ${ }^{13,14}$

In this study most of the doctors (65-80\%) viewed antibiotic resistance as a national problem and as well as at our clinical practice. The recent studies have found a higher level of awareness of the problem of antibiotic resistance training for the better awareness of antibiotic resistance in our hospital setup, although one survey of internal medicine doctors found that previous personal experience with resistance was the best predictor of better recognition of the problem of antibiotic resistance in patients. ${ }^{13-15}$ 
It indicates that from our study, institutions should advocate and arrange for more frequent educational activities and workshops to train fresh graduates regarding current and latest guidelines in the field of antibiotic resistance in order to keep them up to dated with the latest protocol and resistance pattern on local patient's data. Especially concerning intravenous-oral switch criteria, antibiotic combination choice criteria and optimal duration of antibiotic treatment.

Attitude regarding the different components of antibiotic prescribing process and pattern varied according to the scenario studies in our questionnaires. In present study, MBBS interns were most confident, when making a diagnosis and less confident in streamlining or stopping antibiotics therapy, planning the correct duration of treatment or using a combination therapy appropriately.

The high level of confidence reported in our study in making the current diagnosis is not much supported by proper evidence, as misdiagnosis has been shown to be the leading cause of unnecessary antibiotics prescription. ${ }^{16}$

However restriction of prescription of some antibiotics was perceived as helpful by the major of respondents. This step of antibiotics restriction should be very necessarily perceived by the doctors at our hospital and required necessary initiation. Availability of advice from an infection disease specialist and a daily based microbiologist and clinical pharmacist including audit and feedback strategies were also highly valued by participated doctors. These findings are consistent with an Australian and Indian studies survey on medical staff attitudes to an antibiotic approval and stewardship programme. ${ }^{17,18}$

The government, medical institutions, hospital and policy makers need to take intensive action to crab the everygrowing problem of antibiotic resistance and MBBS students, residents and junior doctors should be the earliest targets of these interventions. So that they can inculcate good prescribing habits early in the course of their practice. However, our study has some limitations. In our case the participants are not representative of the population at large as the study population comprised only young medical graduates and junior residents with less senior doctors were respondents. Also the possibility that participants were more inclined to give more favourable answer cannot be ruled out.

Since the study was based on self-reporting, we cannot be much sure that the answer given by them truly reflects their attitude and practice. But the study highlights very significant issues that need to be tackled urgently and appropriately.

\section{CONCLUSION}

The finding demonstrates that participant doctors have a lack of awareness on antibiotic use and resistance. Further qualitative and quantitative studies are needed to identify the determinants of attitude behaviour and motivation that lead people to use and misuse antibiotic. In addition, the government should require its health care system to develop proper regulation and prescription policy as well as controls for prescription of antibiotic drugs. Pharmacist plays a key role in raising awareness about the use of antibiotics and on growing antibiotic resistance with in population.

Finally, public health strategies-including educational programme should be developed, targeting specific area of antibiotics and identification of population at risk in term of improper antibiotic consumption.

\section{ACKNOWLEDGEMENTS}

Our sincere thanks to the entire participant doctors.

Funding: No funding sources

Conflict of interest: None declared

Ethical approval: The study was approved by the Institutional Ethics Committee

\section{REFERENCES}

1. Coast J, Smith R, Miller M. Superbugs: should antimicrobial resistance be included as a coast in economic evaluation? Health economic.1996;5:21726.

2. Quavi A, Zageal-Maurer S, Mariano N, Urban C, Rosenburg C, Burns $\mathrm{J}$, et al. Increased mortality associated with a clonal outbreak of Ceftaxidimerersistant Klebsiella pneumomise: a case- control study. Infect control Hospital Epidemol. 2005;26:238.

3. Okeke IN, Laxminarayan R, Bhutta ZA, Duse AG, Jenkins $\mathrm{P}$, O'Brien TF, et al. Antimicrobial resisitance in developing countries. Part I; Recent trends and current status. Lancet Infect Dis. 2005;5(8):481-93.

4. Norrby SR, Nord CE, Finch R. Lack of development of new antimicrobial drugs: A potential serious threat to public health. Lancet Infect Dis. 2005;5(2):115-9.

5. Pulcini C, Williams F, Molinari N, Davey $P$, Nathwani D. Junior doctors' knowledge and perceptions of antibiotic resistance and prescribing: a survey in France and Scotland. Clin Microbiol Infect. 2011;17(1):80-7.

6. Dellit TH, Owens RC, McGowan JE Jr, Gerding DN, Weinstein RA, Burke JP, et al, infectious disease society of America and the society for healthcare and epedemiology of America guidelines for developing an institutional program to enhance antimicrobial stewardship. Clin Infect Dis. 2007:44:159-77. 
7. Pulcini C, Cua E, Lieutier F, Landraud L, Dellamonica P, Roger PM. Antibiotic misuse: a prospective clinical audit in a French university hospital. Eur J Clin Microbiol Infect Dis. 2007;26:277-80.

8. Stephenson J. CDC campaign targets antimicrobial resistance in hospitals. JAMA. 2002;287:2351-2.

9. World health organization. Prevention and containment of antimicrobial resistance. Available at: http://www.searo.who.int/entity/antimicrobial_resista nce/sea_cd_273.pdf?ua=1. Accessed 15 February 2016.

10. Directorate general of health service. National policy for containment of antimicrobial resistance India. Available at: http://www.ncdc.gov.in/ writereaddata/ linkimages/amr_policy1600931343.pdf. Accessed 15 February 2016.

11. Dellit TH, Owens RC, McGowan JE Jr, Gerding DN, Weinstein RA, Burke JP, et al. Infectious Disease Society of America and the Society for Healthcare Epidemiology of America guidelines for developing an institutional program to enhance antimicrobial stewardship. Clin Infect Dis. 2007;44:159-77.

12. Wester CW, Durairaj L, Evans AT, Schwartz DN, Husain S, Martinez E. Antibiotic resistance: A survey of Physician perception. Arch Med. 2002;162:22106.

13. Wester CW, Durairaj L, Evans AT, Schwartz DN, Husain S, Martinez E. Antibiotic resistance: a survey of physician perceptions. Arch Intern Med. 2002;162:2210-6.

14. Srinivasan A, Song X, Richards A, SinkowitzCochran R, Cardo D, Rand C. A survey of knowledge, attitudes, and beliefs of house staff physicians from various specialties concerning antimicrobial use and resistance. Arch Intern Med. 2004;164:1451-6.

15. Pulcini C1, Williams F, Molinari N, Davey $P$, Nathwani D. Junior doctors' knowledge and perception of antibiotic resistance and prescribing: a survey in France and Scotland. Clin Microbiol Infect. 2011;17:80-7.

16. Pulcini C, Cua E, Lieutier F, Landraud L, Dellamonica P, Roger PM. Antibiotic misuse: a prospective clinical audit in a French university hospital. Eur J Clin Microbiol Infect Dis. 2007;26:277-80.

17. Bruce J, MacKenzie FM, Cookson B, Mollison J, Van der Meer JW, Krcmery V, et al. Antibiotic stewardship and consumption: findings from a panEuropean hospital study. J Antimicrob Chemother. 2009;64(4):853-60.

18. Bharani KY, Sekhar S, Hanumanth N, Palaparthi L. A KAP study regarding antimicrobial resistance among medical students in South India. IOSR J Dent Med Sci. 2015;14(4):110-3.

Cite this article as: Kalyani M, Janagond A, Koshy N, Cheriyan R, Keshannanvar MG, Shalavadi M, et al. A study of knowledge, attitude and practice on use of antibiotics and its resistance among the doctors and interns at urban tertiary care hospital: an interventional study. Int J Basic Clin Pharmacol 2020;9:538-46. 